\title{
PERTUMBUHAN EKONOMI KREATIF MASYARAKAT SEKITAR HUTAN LINDUNG DAN HUTAN PRODUKSI DI KECAMATAN NGANCAR KABUPATEN KEDIRI
}

\author{
*Suwarno ${ }^{1)}$, Rizki Yudha Bramantyo ${ }^{2)}$ \\ 1)Prodi Studi Administrasi Publik Universitas Kadiri, Indonesia \\ 2) Prodi Studi Administrasi Publik Universitas Kadiri, Indonesia \\ *Email Korespondensi : suwarno@unik-kediri.ac.id
}

\begin{abstract}
Abstrak
Saat ini, luas hutan terus berkurang. Begitu juga dengan luas lahan pertanian juga terus berkurang dan berganti dengan tumbuhnya permukiman dan berbagai bangunan serta berbagai fasilitas. Hal demikian memerlukan berbagai lapangan kerja guna memenuhi kebutuhan manusia. Oleh karena itu keberadaan hutan lindung maupun hutan produksi yang berdekatan dengan permukiman penduduk banyak mengalami masalah dan berujung pada konflik. Pendekatan penelitian yang digunakan adalah pendekatan deskriptif dengan teknik purposive. Adapun data yang telah terkumpul dilakukan uji keabsahan data dan analisis penelitian menggunakan teknik analisis interaktif. Hasil penelitiannya adalah Masyarakat sekitar hutan merasa diberdayakan dengan cara melibatkan masyarakat dalam pengelolaan hutan yaitu dengan memberikan lahan garapan pertanian. Pihak Perhutani juga memberikan ijin kepada masyarakat yang tergabung dalam LMDH untuk mengembangkan dan memanfaatkan sebagian kecil kawasan hutan untuk diberdayakan sesuai kemampuan penduduk. Melalui renungan, pemikiran, ide dan gagasan serta pengembangan keterampilan sebagian masyarakat yang dapat menjadi bisnis, sehingga bermunculan berbagai objek wisata. Demikian juga dengan keberadaan pasar tradisional dan kuliner lokal sehingga pertumbuhan dan pendapatan kesejahteraan masyarakat mejadi meningkat. Pertumbuhan ekonomi terus berkembang baik itu dalam bidang peningkatan kualitas dan jaringan sosial.
\end{abstract}

Kata Kunci: Ekonomi Kreatif; Hutan Lindung; Hutan Produksi

\begin{abstract}
Currently the forest area continues to decrease. Likewise, the area of agricultural land also continues to decrease and change with the growth of settlements and various buildings and various facilities. This requires a variety of jobs to meet human needs. Therefore, the existence of protected forests and production forests adjacent to human settlements has encountered many problems and has resulted in conflicts. The research approach used is a descriptive approach with purposive techniques. The data that has been collected is tested for data validity and research analysis using interactive analysis techniques. The result of his research was that the people living around the forest felt empowered by involving the community in forest management, namely by providing agricultural arable land. Perhutani also gave permission to the people who are members of the LMDH to develop and utilize a small part of the forest area to be empowered
\end{abstract}


according to the capacity of the population. Through reflections, thoughts, ideas and ideas as well as the development of skills of some people who can become businesses, so that various tourist objects emerge. Likewise with the existence of traditional markets and local culinary so that the growth and income of the people's welfare increases. Economic growth continues to develop both in the field of quality improvement and social networks.

Keywords: Creative economy; Protected forest; Production forest

\section{PENDAHULUAN}

Tidak bisa dipungkiri lagi bahwa pertumbuhan penduduk Indonesia sangat pesat (1,49\%/tahun) itu sama dengan rata-rata setiap keluarga memiliki 2 sampai 3 anak dan jika dijumlah menjadi 4,5 juta jiwa/tahun. Jumlah penduduk demikian sama dengan jumlah penduduk Singapura. Jika demikian dapat diprediksi bahwa 20 tahun lagi bayi yang baru lahir tersebut menjadi penduduk usia produktif dan itu artinya pemerintah harus menyediakan banyak lapangan kerja. Kondisi ini akan tambah menjadi parah dan sangat membahayakan jika penduduk yang lahir menjadi penduduk yang tidak berkualitas atau berasal dari keluarga yang tidak berkualitas. Penduduk yang demikian akan menjadi beban masyarakat, pemerintah dan lingkungan. Oleh karena itu secara demografi pertumbuhan penduduk 1,49\% tersebut memang harus diturunkan menjadi 1,1\%/tahun jika kita ingin lebih cepat mencapai kesejahteraan lahir dan batin atau agar hasil pembangunan menjadi lebih cepat bisa dirasakan hasilnya (Faqih, 2010).

Sementara itu, untuk bisa bersekolah diperlukan biaya yang tidak sedikit, mulai dari seragam, sumbangan sekolah, buku-buku pelajaran, dan lain-lain kebutuhan sekolah. Oleh karena itu masih saja kita jumpai banyyak saudara kita yang kurang beruntung khususnya di daerah-daerah pinggiran atau di pedesaan. Bahkan terkadang di kota-kota besarpun bisa kita jumpai yang mereka seharusnya bersekolah namun karena himpitan ekonomi mereka terpaksa harus ngamen, menggelandang dan meminta-minta sekedar untuk bisa bertahan hidup.

Belum lagi daya dukung lahan untuk menopang kehidupan mereka yang semakin hari semakin menyusut, lahan sawah dan ladang semakin menyusut berubah menjadi lahan perumahan dan lahan industri. Bahkan yang seharusnya hal tersebut tidak terjadi terpaksa atau memang pura-pura tidak tahu mereka harus membangun daerah-daerah yang 
seharusnya tidak boleh dijadikan lahan bangunan atau perumahan, seperti hanya daerah resapan atau daerah penyangga.

Pembangunan perumahan sebagai pemenuhan kebutuhan manusia terus berkembang demikian juga dengan pembangunan industri. Ini berarti luas lahan hijau semakin hari juga semakin menyusut, apalagi luas hutan di pulau jawa. Banyak pennduduk yang kesulitan ekonomi dan tiadanya lahan pertanian pada akhirnya merambah ke hutan, dan biisa jadi merusak hutan atau merusak lingkungan sebagai ekonomi alternatif. Agar hal yang demikian tidak berlangsung terus, maka sangat dianjurkan kepada masyarakat ataupun pemangku kepentingan dan penguasa untuk selalu bisa menciptakan lingkungan hijau dimana saja berada, misalnya di lingkungan sekolah, lingkungan perkantoran, lingkungan industri, lingkungn pasar, pelabuhan maupun di kiri dan kanan jalan.

Indonesia dewasa ini memiliki kawasan hutan negara seluas 112,3 juta Ha, yang terdiri dari hutan produksi 64 juta Ha, hutan lindung 29,3 juta Ha, dan hutan konservasi seluas 19 juta Ha. Hal inipun bertambah hari bisa jadi sudah menyusut dan hal tersebut menjadi tugas kita bersama untuk tetap melestarikan lingkungan hutan. Hutan merupakan satu kesatuan ekosistem berupa hamparan lahan berisi sumber daya hayati yang didominasi pepohonan dalam persekutuan alam lingkungannya, yang satu dengan lainnya tidak dapat dipisahkan (Barus et al., 2015).

Kawasan hutan yang berdekatan dengan areal pertanian penduduk atau berdekatan dengan permukiman, pengelolaannya, khususnya pengawasan baik itu tanaman maupun hasil hutan, perlindungan hutan secara murni oleh Dinas Kehutanan tanpa campur tangan masyarakat. Mengingat besarnya ancaman dari tindakan pencurian ataupun perusakan hutan. Apalagi terhadap tanaman hutan baru setelah selesai ditebang. Kawasan hutan yang berdekatan dengan permukiman penduduk sudah hampir tidak ada lagi yang memang murni hutan. Hal tersebut oleh pemerintah dalam hal ini Dinas Kehutanan dimanfaatkan oleh pemerintah untuk areal hutan produksi ataupun hutan lindung, melalui tanaman sengon, jati mas dan tanaman lain yang merupakan bahan produksi seperti kertas dan lain sebagainya. Sistem pengawasan hutan demikian oleh Dinas Kehutanan bekerja sama dengan masyarakat sekitar hutan dengan cara masyarakat sekitar hutan tersebut 
diperkenankan untuk menanami kawasan hutan dengan tanaman pertaniaan, seperti ketela pohon, jagung, cabe, nanas.

Demikian juga yang terjadi di lereng Gunung Kelud sebelah barat yang merupakan wilayah Kabupaten Kediri, khususnya di wilayah Kecamatan Ngancar. Wilayah lereng Gunung Kelud sebelah barat yang masuk wilayah Kecamatan Ngancar dikelola oleh Perusahaan Perkebunan Margo Mulyo. Awalnya perkebunan mengelola tanaman kopi, namun dewasa ini tanaman kopi sudah hampir punah. Punahnya tanaman kopi tersebut sebagai akibat abu vulkanis dari letusan Gunung Kelud terakhir yaitu tahun 2014. Namun sisa tanaman kopi dan tanaman cengkeh yang ada masih dikelola dengan baik, dan kawasan lainnya ditanami tanaman nanas, tebu melalui kerjasama dengan masyarakat sekitar desa Sugih Waras yang merupakan desa terakhir untuk menuju ke Gunung Kelud. Hampir seluruh aktivitas pertanian dan peternakan mereka memanfaatkan kawasan lereng Gnung Kelud yang sebenarnya hal tersebut sebagaian merupakan wilayah perkebunan Margo Mulyo dan sebagaian lagi kawasan hutan lindung. Hal ini dapat terjadi karena memang harus disadari bahwa penduduk terus bertambah, dengan berbagai kebutuhan hidup yang mengiringinya, sementara itu daya dukung lahan yang ada semakin terbatas untuk dapat memenuhi kebutuhan manusia tersebut. Demikian juga dengan luas hutan yang juga semakin menyusut. Padahal keberadaan hutan atau lingkungan hijau sangat diperlukan oleh manusia, dan jika dibiarkan lingkungan hutan bisa rusak oleh ulah manusia. Oleh karena itu pemanfaatan kawasan hutan oleh masyarakat harus dikelola atau diatur dengan bijaksana, sehingga bisa sama-sama menguntungkan kedua belah pihak. Demikin juga dengan perusahaan perkebunan milik daerah yang dipercaya untuk mengelola wilayah atau lereng dari daerah pegunungan untuk tanaman perkebunan sehingga dapat menjadi pendapatan daerah dari sektor tanaman perkebunan. Bagaimana manfaat dan dampak yang diperoleh oleh masyarakat sekitar hutan dan derah perkebunan sebagai akibat keberadaan hutan dan perkebunan serta kendala apa yang dialami dalam masalah pemanfaatan kawasan hutan tersebut. 


\section{TINJAUAN PUSTAKA}

Di Pulau Jawa luas hutan sudah semakin berkurang dan mungkin sudah tidak sanggup lagi sebagai daerah penyanggah atau resapan air. Hutan serasa hidup berdampingan dengan masyarakat, dan banyak lagi masyarakat yang hidupnnya bergantung pada hutan. Konsep hutan dewasa ini bukan lagi sebagai sesuatu yang menakutkan, banyak binatang buas, tempat bermukim harimau dan berbagai binatang buas lainnya. Justru hutan menjadi objek wisata, objek ilmu pengetahuan dan inspirasi serta sumber ekonomi (Barus et al., 2015)

Menyadari bahwa masyarakat sekitar hutan menggantungkan hidupnya dari hutan dan agar tidak merusak hutan serta ikut menjaga kelestarian hutan maka masyarakat tersebut diberi kesempatan untuk menggarap lahan hutan yang pohonnya baru ditebang, dan semampang menunggu tanaman baru tumbuh besar maka masyarakat sekitar hutan bisa bertani di lahan tersebut, hal demikian disebut dengan petani pesanggem. Para petani pesanggem tersebut menanami lahan perhutani dengan tanaman padi gogo, jagung, kacang tanah, dan atau ketela pohon, dan sementtara lahan yang menjadi pembatas atau pinggiran ditanami dengan pohon lamtoro. Ini dapat diartikan bahwa hutan merupakan daya dukung bagi kehidupan masyarakat sekitar hutan (JATMININGSIH, 2010)

Menurut (Prastyo \& Hidayat, 2016) menjelaskan bahwa pengelolaan Perum Perhutani masa lalu cenderung timber oriented, yang mana kurang memperhitungkan variabel sosial ekonomi dan budaya. Ini kemudian memunculkan disparsitas atau ketidakseimbangan dalam pemanfaatan sumber daya hutan dan meningkatnya konflik pengelolaan dengan masyarakat sekitar hutan. Hingga lahirlah paradigma baru pengelolaan sumberdaya hutan yang berbasis pada pemberdayaan masyarakat melalui kesadaran berbagi hasil, berbagi peran dan berbagi tanggung jawab.

Oleh karena itu pemerintah untuk menjaga kelestarian hutan, khususnya dari pengrusakan hutan maka pemerintah berupaya untuk meningkatkan penjagaan dengan membangun perumahan perhutani dan mengajak masyarakat sekitar hutan. Bentuk kerja sama tersebut yang kemudian dikenal dengan pesanggem dan itu terjadi pada awal tahun 1970an (Susilo et al., 2017). 
Payung hukum tentang kemitraan kehutanan tersebut diatur oleh peraturan Menteri Lingkungan Hidup dan Kehutanan No. P.83/MenLHK/Setjen/Kum.1/10/2016. Kemitraan kehutanan tersebut lahir karena hutan sebagai salah satu bentuk perhutanan sosial. Sesuai dengan namanya yaitu perhutanan sosial, artinya fungsi sosial dari hutan, berarti keberadaan hutan tidak lepas dari manfaat dan interaksi antara masyarakat dan hutan itu sendiri yang hendak dimaksimalkan. Melalui kegiatan tersebut dapat diperoleh berbagai keuntungan dari kedua belah pihak. Masyarakat diuntungkan karena dapat menikmati lahan hutan untuk kegiatan pertanian, menikmati sebagian kecil hasil hutan. Hal tersebut secara lebih rinci Nur menjelaskan bahwa kemitraan kehutanan merupakan salah satu bentuk dari Perhutanan Sosial yang dilakukan antara masyarakat setempat dengan pengelola hutan, pemegang izin pemanfaatan hutan/jasa hutan, izin pinjam pakai kawasan hutan, atau pemegang izin usaha industri primer hasil hutan (Fuaddi, 2020).

Peraturan pemerintah yang mengatur tentang program kemitraan kehutanan adalah Peraturan Menteri Kehutanan Republik Indonesia Nomor: P.39/Menhut-II/2013 tentang Pemberdayaan Masyarakat setempat melalui Kemitraan Kehutanan. Program Kemitraan kehutanan merupakan program pemberdayaan masyarakat oleh kehutanan, oleh karena itu hukumnya wajib bagi KPH. Adapun yang dimaksudkan dengan pemberdayaan masyarakat menurut BAB I Ketentuan umum pasal 1 adalah pemberdayaan masyarakat setempat melalui Kemitraan Kehutanan yang merupakan upaya untuk meningkatkan kemampuan dan kemandirian masyarakat setempat untuk mendapatkan manfaat sumber daya hutan secara optimal dan adil melalui Kemitraan Kehutanan dalam rangka peningkatan kesejahteraan masyarakat setempat.

Izin Usaha Pemanfaatan Hasil Hutan Kayu (IUPHHK) dan/atau IzinUsaha Pemanfaatan hasil Hutan Bukan Kayu (IUPHHBK) dalam hutan tanaman adalah izin usaha yang diberikan untuk memanfaatkan hasil hutan berupa kayu dan/atau bukan kayu dalam hutan tanaman padahutan produksi melalui kegiatan penyiapan lahan, pembibitan, penanaman, pemeliharaan, pemanenan, dan pemasaran (Indonesia, 2011)

Adapun yang dimaksud dengan KPH adalah Kesatuan Pengelolaan Hutan yaitu wilayah pengelolaan hutan sesuai fungsi pokok dan peruntukannya, yang dapat dikelola secara efisien dan lestari. Adapun ketentuan areal kemitraan kehutanan, meliputi (1) areal 
konflik dan yang berpotensi konflik; (2) areal yang memiliki potensi dan menjadi sumber penghidupan masyarakat setempat; (3) luas areal maksimal 2 hektar untuk setiap kepala keluarga; (4) pada areal yang sedang berkonflik, diatur sesuai kondisi lapangan dan secara bertahap luas areal dibatasi 2 hektar; dan (5) batasan luas maksimal 2 hektar, tidak berlaku pada kerjasama pemungutan HHBK atau Jasling (BAB IV Pelaku Kemitraan Kehutanan Pasal 7, 10 dan 11).

Menurut (Hartley et al., 2015) mendeskripsikan tentang ekonomi kreatif yaitu: "The creation of value as a result of idea", yang secara umum dapat diartikan bahwa masyarakat yang sebagian besar waktunya dihabiskan untuk menghasilkan ide, tidak hanya melakukan hal yang bersifat rutin saja. Sebab diyakini bahwa ide dapat menghasilkan kemajuan. Jika demikian maka keberadaan sumber daya manusia memeganag peranan atau basic dari ekonomi kreatif. Sesuai dengan namanya ekonomi kreatif, berarti pengembangan ekonomi yang berdasar pada kreatifitas. Sementara itu kreatifitas manusia dapat berkembang apabila didukung dengan pengetahuan, pergaulan, pengamatan, pengalaman hidup. Artinya bersumber pada daya pikir, nalar, rasa, lahirlah karsa (mencipta atau dayaq untuk mencipta), sehingga ketrampilan dan skill. Muara dari aktifitas pikir, yang menghasilkan ide atau gagasan tersebut adalah dihasilkan temuan atau sesuatu yang memiliki nilai jual atau nilai ekonomi (suatu karya) dan tidak menutup kemungkinan hal tersebut menjadi profesi atau pekerjaan baru.

Menurut studi yang dilakukan oleh UNCTAD (United Nations Conference on Trade and Development) di tahun 2010, ekonomi kreatif adalah "An evolving concept based on creative assets potentially generating economic growth and development." Dapat deiartikan swecara bebas yaitu perkembangan ekonomi dengan berbasis pada kreatifitas, sehingga berpotensi pada pertumbuhan dan perkembangan ekonomi. Adapun indikator ekonomi kreatif antara lain :

a. Gagasan atau ide sebagai fondasi

b. Didukung oleh keahlian, bakat dan ketrampilan

c. Perlu adanya dukungan pemerintah, LSM, atau berbagai pihak untuk bisa lebih berkreasi.

d. Dapat dikembangkan pada bidang yang tidak terbatas dan bersifat relatif. 


\section{METODE PENELITIAN}

Suatu ilmu pengetahuan tidak akan berkembang tanpa penelitian. Oleh karena itu penelitian meruoakan bagian yang sangat urgen dalam ilmu pengetahuan dan melindunginya dari kehancuran. Melalui penelitian suatu ilmu pengetahuan akan terperbaharui (up to date), terperbarukan, aplicated, dan aksiologis bagi penggunanya. Adapun pendekatan kualitatif adalah sebagai prosedur penelitian yang menghasilkan data deskriptif berupa kata-kata tertulisatau lisan dari orang-orang dan perilaku yang dapat diamati(Arikunto, 2010). Mendasarkan pada karakter tema dan masalah dalam penelitian in, maka pendekatan yang tepat untuk dapat menjawab permasalahan dalam penelitian ini adalah dengan pendekatan kualitatif.

Adapun penelitian kualitatif memiliki tahapan-tahapan, yaitu tahapan berpikir kritis ilmiah, maksudnya adalah seorang peneliti memulai berpikir kritis secara induktif yaitu menangkap berbagai fakta atau fenomena-fenomena sosial, melalaui pengamatan di lapangan, kemudian menganalisisnya dan lalu berupaya melakukan teorisasi berdasarkan pada apa yang diamati tersebut menjadi jawaban sementara ilmiah (Hamdi \& Bahruddin, 2015). Ini berarti karya penelitian kualitatif didasari oleh proses berpikir induktif guna menemukan jawaban logis terhadap apa yang menjadi fokus penelitian, sehingga hasil dri proses berpikir induktif tersebut menjadi jawaban sementara terhadap apa yang menjadi permasalahan dalam penelitiannya, hal inilah yang disebut proses berpikir induktif analistis.

Sementara itu Anselm Strauss dan Juliet Corbin dalam bukunya Dasar-dasar Penelitian Kualitatif menjelaskan tentang penelitian kualitatif yaitu sebagai jenis penelitian yang temuan-temuannya tidak diperoleh melalui prosedur statistik atau bentuk hitungan lainnya (Corbin \& Strauss, 2014). Selanjutnya Corbin memberikan contoh penelitian kualitatif,misalnya penelitian tentang kehidupan, riwayat, perilaku,organisasi, pergerakan masyarakat/sosial, dan atau suatu hubungan atau interaksi sosial.

Adapun menurut Bagong Suyanto dkk, menjelaskan bahwa yang menjadi karakter pada pendekatan penelitian kualitatif anttara lain : (1). Bersifat Induktif., (2). Melihat pada setting dan manusia sebagai satu kesatuan. (3). Memahami perilaku manusia dari sudut 
pandang mereka sendiri (sudut pandang yang cermat). (4). Lebih mementingkan proses penelitian dari pada hasil. (5). Menekankan pada validitas data. (6). Bersifat humanitis. (7). Semua aspek kehidupan sosial dan manusia dianggap berharga dn penting untuk dipahami karena dianggap bersifat spesifik dan unik (Suyanto, 2015).

Mendasarkan pada berbagai deskripsi dari berbagai pandangan para pakar tentang pendekatan kualitatif sebagaimana tersebut di atas, maka sangat proporsional apabila dalam penelitian ini menggunakan pendekatan kualitatif, mengingat permasalahan dalam penelitian ini adalah tentang perilaku manusia, tentang motivasi hidup suatu kelompok masyarakat, tentang interaksi timbal balik antara keberadaan hutan dengan lingkungan masyarakat sekitar hutan, dan tentang peningkatan kesejahteraan sebagai dampak dari keberadaan hutan.

Penelitian ini dilakukan di lereng barat Gunung Kelud yang masuk wilayah kecamatan Ngancar. Alasannya adalah :

a. Daerah lereng barat gunung Kelud, khususnya daerah kecamatan Ngancar meruakan daerah yang terdekat dengan aktivitas gunung Kelud, sehhingga di daerah tersebut masih resent atau daerah yang paling besar terkena dampak letusan gunung Kelud.

b. Masyarakatnya bekerja sebagai petani dan menggantungkan pekerjaan dari lahan hutan yang ada di daerah setempat.

c. Di daerah tersebut lahannya subur sebagai dampak letusan gunung Kelud.

d. Masyarakatnya memiliki motivasi hidup yang tinggi dalam beraktivitas, guna memperjuangkan hidup.

e. Walaupun daerah tersebut paling besar terkena dampak letusan gunung Kelud, namuan mereka tidak mau dipindahkan ke daerah lain.

Informan merupakan orang yang dianggap memiliki informasi terkait dengan penelitian yang dilakukan. Mengingat orang yang demikian tersebut diperlukan berbagai agen data, maka keberadaanya harus sesuai dengan karakter data yang nantinya dikomparasi dengan permasalahan penelitian dan tujuan yang ingin dicapai. Oleh karenaa itu harus diseleksi sesuai dengan gradasai permasalahan. Adapun teknik yang digunakan untuk menentukan informan adalah dengan teknik purposive, yaitu penentuan informan 
dengan alasan tertentu yang dapat dibenarkan secara ilmiah. Adapun yang menjadi pertimbangn dalam penentuan informan adalah sebagai berikut :

a. Informan tersebut merupakan pelaku dari kegiatan objek penelitian, baik dari pihak perhutani maupun masyarakat sekitar hutan.

b. Informan merupakan penduduk asli atau warga setempat yang memang berdomisili di kawasan sekitar hutan.

c. Informan sebisa mungkin mewakili struktur yang ada di masyaarakat.

Setiap data yang dikumpulkan yang nantinya digunakan dalam analisis data. Agar hasil penelitian tersebut dapat dipertanggungjawabkan kebenarannya, maka data tersebut harus teruji keabsahan datanya. Oleh karena itu data harus teruji melalaui uji keabsahan data, melalui tahapan sebagaimana dikemukakan oleh (Faradina, 2017), ada empat yaitu: standar kredibilitas, standar transferabilitas, standar dependabilitas dan standar konfirmabilitas.

a. Standar kredibilitas adalah terpenuhinya persyaratan validitas internal, yang ditempuh dengan mengamati, mencermati, mengenali secara langsung, serta memahami dengan baik dan mendalam bagaimana interaksi sosial dalam kegiatan.

b. Standar transferabilitas adalah terpenuhinya validitas eksternal, yang dilakukan dengan mencari sebanyak mungkin gambaran tentang konteks yang melingkupi obyek penelitian;

c. Standar dependabilitas adalah terpenuhinya persyaratan reliabilitas, yang dilakukan dengan mencermati padu tidaknya suatu konsep, kategori, atau. penarikan kesimpulan dengan data yang tersedia termasuk kenyataan yang ada di lapangan itu sendiri;

d. Standar konfirmabilitas, yaitu terpenuhinya persyaratan obyektivitas, yang dilakukan dengan mencermati padu tidaknya hasil penelitian secara keseluruhan dengan data dan kenyataan lapangan.

Kemudian dilanjutkan dengan uji validasi data melalui teknik triangulasi, yaitu cara untuk melakukan pengecekan atau pembandingan terhadap data yang telah dikumpulkan. (Hadi, 2017) menjelaskan ada empat macam triangulasi yang dapat dilakukan, yaitu triangulasi dengan sumber, triangulasi dengan metode, triangulasi 
dengan penyidik, dan triangulasi dengan teori. Melalui triangulasi ini akan dihilangkan perbedaan-perbedaan konstruksi kenyataan yang ada dalam konteks.

Menurut (Arikunto, 2010) berpendapat bahwa dengan triangulasi peneliti dapat me-recheck temuannya dengan jalan membandingkanya dengan berbagai sumber (pakar), metode, teori, atau data. Untuk itu maka peneliti dapat melakukannya dengan jalan (1) mengajukan berbagai macam variasi pertanyaan; (2) mengeceknya dengan berbagai sumber data; dan (3) memanfaatkan berbagai metode agar pengecekan kepercayaan data dapat dilakukan. Dalam implementasinya di lapangan triangulasi yang dilakukan pada umumnya meliputi triangulasi dengan sumber, pengecekan balik derajat kepercayaan suatu informasi atau data yang diperoleh dengan membandingkannya dengan pendapat orang lain yang berbeda dan juga pandangan pakar. Hasil pembandingan ini tidak hanya diperoleh kesamaan atau perbedaan pandangan, pendapat, atau pemikiran dari berbagai sumber informasi tetapi juga alasan-alasan terjadinya perbedaan-perbedaan tersebut. Teknik pengumpulan data dengan menggunakan teknik observasi, wawancara dan dokumentasi. Langkah terakhir yaitu dengan melakukan analisis data dengan teknik analisis data interaktif dari Milles dan Huberman.

\section{HASIL DAN PEMBAHASAN}

Pelaksanaan Kawasan Hutan lindung dan hutan produksi di wilayah Kecamatan Ngancar tersebut bekerjasama dengan Perhutani Kediri untuk memberikan fasiltas atas keberadaan Lembaga Masyarakat Desa Hutan (LMDH) di Wilayah Kecamatan Ngancar dan Ngasem. Hal tersebut menciptakan lapangan kerja baru bagi petani sekitar hutan yang telah tergabung dalam LMDH dengan menanam jagung, nanas, cabai, kacang panjang, singkong. Upaya demikian sangat baik dan berdwifungsi guna, di stu sisi membuka lapangan kerja, disi yang lain dapat menciptakan upaya pelestrian hutan, menjaga hutan dan mengelola hutan tanpa merusak tanaman hutan. Jika sudah demikian hal tersebut berdampak pada peningkatan perekonomian masyarakat.

Sudah disadari bahwa pemberdayaan masyarakat sekitar hutan sangat penting dan nyata-nyata dapat membawa kemajuan bagi hutan, kemajuan bagi petani dan pertanian, dan juga berdaya guna bagi upaya pelestarian hutan. Oleh karena itu masyarakat sekitar 
hutan di wilayah Kecamatan Ngancar memiliki lembaga yang disebut dengan Lembaga Masyarakat Desa Huta (LMDH) yang merupakan wadah masyarakat sekitar hutan tentang keberadaan tanaman yang mereka tanam dan sekaligus keberdayaan hutannya itu sendiri.

Di Kecamatan Ngancar Kabupaen Kediri yang secara geografis terletak di sebelah barat dan tenggara lereng gunung Kelud tersebut memiliki dua kawasan perkebunan, yaitu perkebunan kopi di PT. Margo Mulyo dan Perkebunan Sumbersari Petung Desa Sempu Kecamatan Ngancar. Perkebunan di Sumbersari desa Petung tersebut merupakan peninggalan zaman Belanda. Beragam tanaman ditanam di lahan seluas kebun $400 \mathrm{Ha}$, seperti tebu, cengkeh dan karet. Sementara anggrek dikelola di lahan seluas 5Ha dan menempati bagian depan perkebunan.

Semakin ke timur memiliki kondisi geomorfologi bergelombang. Oleh karena itu jeniis tanaman yang dapat di tanam oleh masyarakat di wilayah Kecamatan Ngancar menyesesuaikan dengan kondisi lahan tersebut. Minimnya kondisi perairan (irigasi) berakibat di daerah tersebut hanya dapat diusahakan sebagai pertanian lahan kering. Ragam tanaman yang sering diupayakan olah masyarakaat antara lain tanaman jagung, ketela pohon, tebu, nanas, pepaya, kacang panjang, cabe dan lain sebagainya. Tanaman sebagaimana tersebut di atas, ditanam pada musim kemarau, kecuali tebu dan pepaya.

Mendasarkan pada fakta di lapangan bahwa masyarakat Kecamatan Ngancar sebelah timur yang menuju ke arah gunung Kelud berbatasan dengan wilayah perkebunan dan daerah gunung Kelud yang berdampak pada masyarakat di daerah tersebut bekerja di perkebunan sebagai buruh di perkebunan tersebut. Namun dengan keluarnya peraturan pemerintah tentang pemberdayaan masyarakat sekitar hutan dalam pengelolaan hutan, maka masyarakat sekitar hutan tersebut tidak lagi hanya bekerja di perkebunan, namun juga mengola lahan hutan untuk dijadikan lahan pertanian dengan tanaman jangka pendek dan tanamaan yang mendukung pasar lokal, seperti jagung, kacang panjang, terong dan nanas.

Dalam menindaklanjuti peraturan menteri kehutanan tentang pemberdayaan masyarakat sekitar hutan dalam pengelolaan hutan Perhutani Kecamatan Ngancar membentuk kerjasama dengan masyarakat. Kerjasama tersebut dilakukan bisa secara individu maupun secara bersama (kelompok). Kerjasama tersebut dilakukan dalam rangka 
mencapai tujuan bersama yaitu bagi masyarakat untuk meningkatkan kesejahteraan masyarakat. Adapun bagi perhutani dalam rangka menyelesaikan berbagai masalah yang terjadi antara pihak perhutani dengan masyarakat, disamping untuk memaksimalkan pengelolaan hutan, khususnya wilayah hutan yang berbatasan atau bersinghungan dengan masyarakat.

Pengelolaan hutan bersama masyarakat dimaksud antara lain dalam memelihara hutan tanaman industri, meminimalisir berbagai permasalahan yang terjadi di daerah hutan yang bersinggungan dengan permukiman penduduk (masyarakat), memaksimalkan upaya pelestariaan lingkungan, dan memaksimalkan produktivitas hutan. Tindakan pengelolaan tersebut diwujudkan dengan membentuk lembaga atau bentuk kerjasama tersebut adalah Pengelolaan Hutan Bersama Masyarakat (PHBM).

Pengelolaan hutan bersama masyarakat ini sebagai hasil dari implementasi program Pengelolaan Hutan Bersama Masyarakat (PHBM), kegiatan pengelolaan bersama masyarakat tersebut ternyata dapat lebih memberdayakan masyarakat sekitar hutan khususnya dibidang pertanian dan membantu dinas perhutani dalam hal pengawasan dan pemeliharaan tanaman muda di kawasan hutan serta usaha pelestarin hutan. Kerjasama tersebut menguntungkan kedua belah pihak, baik itu pihak pemerintah maupun bagi masyarakat. Masyarakat sekitar hutan sekarang sudah memiliki lahan garapan untuk pertanian, pekerjaan, membantu mengawasi dan melindungi kerusakan lingkungan.

Melalui pengelolaan bersama khususnya hutan lindung dan hutan produksi tersebut membawa berbagai manfaat yang dapat dirasakan kedua belah pihak, manfaat tersebut antara lain :

a. Hutan lindung maupun hutan produksi terbebas dari ancaman kerusakan hutan maupun lingkungan yang disebabkan oleh berbagai perilaku sosial masyarakat yang merusak hutan. Hal ini sangat dimungkinkan karena masyarakat sudah memiliki lahan garapan pertanian yang diberi oleh dinas perhutani sebagai implementasi program kemitraan dinas kehutanan.

b. Lahan garapan pertanian masyarakat sekitar hutan bertambah yang berdampak pula pada pertambahan penghasilan masyarakat sekitar hutan sebagai akibat dari tanaman 
pertanian atau tanaman sayuran yang mereka kembangkan. Hasil panen mereka diperdagangkan di lokasi-lokasi wisata yang ada di sekitar tempat tinggal mereka. Masyarakat bisa mengembangkan potensi yang dimilkiki untuk terus meningkatkan atau melipatgandakan penghasilan mereka dengan memanfaatkan potensi alam yang ada di sekitar mereka.

c. Lereng barat dan tenggara dari kawasan Gunung Kelud pasca letusan 2014 sangat mempesona yang ditunjang dengan udara yang sejuk, pemandangan yang indah kenampakan alami lereng gunung yang mempesona sungguh menjadi potensi wisata yang bisa dikembangkan.

d. Himpitan ekonomi, tekanan lingkungan untuk terus berkompetisi memenuhi kebutuhan hidup, berdampak pada sebagian masyarakat yang berusaha keras untuk mencari ide dan atau gagasan bagaimana memberdayakan potensi alam yang ada ini untuk dapat menghasilkan sesuatu.

e. Melalui kajian berbagai literatur di internet, google, dan berbagai informasi terkait wisata, maka munculah ide untuk memanfaatkan poptensi alam unjtuk dikembangkan menjadi kawasan wisata.

f. Kawasan wisata yang unik yang ditempat lain tidak ada atau ada tetapi dengan biaya yang mahal atau tempat yang jauh. Maka berkembanglah wisata kampung Indian, Kebun Anggrek, Kebun Strawbery, kawasan sepeda gunung, taman bunga yang indah dan masih banyak lagi.

g. Apa yang dilakukan oleh masyarakat sekitar kawasan hutan lindung maupun hutan produksi di dinas kehutanan Kecamatan Ngancar Kabupaten Kediri, yaitu lereng barat dan tenggara dari kawasan gunung Kelud merupakan uapaya ekonomi kreatif yang mereka kembangkan. Sebab hasil pertanian mereka pasarkan di pasar wisata, demikian juga dengan kuliner lokal.

h. Pemasaran kawasan wisata tersebut sudah melalui mass media sosial, sehingga seluruh penjuru dunia dapat memperoleh informasi tentang wisata Kelud. 


\section{KESIMPULAN DAN SARAN}

\section{Kesimpulan}

Peningkatan kesejahteraan masyarakat yang ada di kawasan lereng barat dan tenggara diri Gunung Kelut merupakan kerja keras dalam mencari ide dan gagasan dalam memberdayakan potensi alam yang dimiliki di daerah tersebut. Hal ini sebagai bentuk pengembangan ekonomi kreatif masyarakat. Penelusuran ide melalui internet, berbagai informasi dan kajian literatur yang ada serta setelah melalui uji perbandingan kondisi di berbagai daerah kemudian munculah ide dan gagasan yang dijual melalui media sosial. Hal tersebut membawa hasil yang luar biasa, karena melalui ide dan gagasan tersebut tercipta suatu kegiatan yang bermanfaat untuk manusia.

\section{Saran}

Disarankan kepada pemerintah terkait agar memberikan kebijakan yang mendukung kegiatan kepariwisataan, karena hal tersebut berarti pemerintah berkontribusi pada ekonomi kerakyatan yang sedang dikembangkan di daerah tersebut. Disamping itu juga disarankan kepada pelaku kegiatan kepariwisataan untuk terus mengembangkan ide dan gagasan agar menjadi sesuatu yang terus baru sehingga menjadi daya tarik wisata yang selalu up to date untuk dinikmati.

\section{REFERENSI}

Arikunto, S. 2010. Metode Peneltian. Jakarta: Rineka Cipta.

Barus, R. M., Syahrin, A., Arifin, S., \& Hamdan, M. 2015. Pertanggungjawaban Pidana Illegal Logging (Pembalakan Liar) sebagai Kejahatan Kehutanan Berdasarkan Undang-undang No. 41 Tahun 1999 Tentang Kehutanan dan Undang-undang No. 18 Tahun 2013 Tentang Pencegahan dan Pemberantasan Perusakan Hutan. USU Law Journal, 3(2), 106-114.

Corbin, J., \& Strauss, A. 2014. Basics of qualitative research: Techniques and procedures for developing grounded theory. Sage publications.

Faqih, A. 2010. Kependudukan: Teori, Fakta dan Masalah. Deepublish.

Faradina, N. 2017. Pengaruh program gerakan literasi sekolah terhadap minat baca siswa di SD Islam Terpadu Muhammadiyah An-Najah Jatinom Klaten. Hanata Widya, 6(8), 60-69. 
Fuaddi, T. 2020. Kerjasama pemanfaatan hutan pada kesatuan pengelolaan hutan ditinjau dari hukum administrasi pemerintahan. Prosiding Simposium Nasional Magister (SINMAG), 4(1).

Hadi, S. 2017. Pemeriksaan Keabsahan Data Penelitian Kualitatif Pada Skripsi. Jurnal Ilmu Pendidikan, 22(1).

Hamdi, A. S., \& Bahruddin, E. 2015. Metode penelitian kuantitatif aplikasi dalam pendidikan. Deepublish.

Hartley, J., Wen, W., \& Li, H. S. 2015. Creative economy and culture: Challenges, changes and futures for the creative industries. Sage.

Indonesia, M. K. R. 2011. Peraturan Menteri kehutanan Republik Indonesia.

JATMININGSIH, T. R. I. 2010. Karakteristik lingkungan, karakteristik petani pesanggem, dan peran masyarakat lokal dalam PHBM KPH Kendal. Universitas Diponegoro.

Prastyo, E. E., \& Hidayat, K. 2016. Pola Kemitraan Antara Perum Perhutani Dengan Masyarakat Desa Hutan (Studi Kasus Program PKPH di Desa Kucur Dau, Kabupaten Malang). HABITAT, 27(3), 139-149.

Susilo, E., Purwanti, P., \& Fattah, M. 2017. Adaptasi Manusia: Ketahanan Pangan dan Jaminan Sosial Sumberdaya. Universitas Brawijaya Press.

Suyanto, B. 2015. Metode Penelitian Sosial: Berbagai Alternatif Pendekatan. Prenada Media. 